\title{
Realne podstawy komunikacji
}

\author{
Real Foundations for Communication
}

\section{Grzegorz PAWLOWSKI}

Uniwersytet Warszawski/ University of Warsaw

E-mail: g.pawlowski@uw.edu.pl,

\begin{abstract}
How is (language) communication possible? What is its real underlying support? What does it mean that subjects communicate with one another? On what paradigm is such communication based: relativised or real? These questions constitute the starting point for propositions I intend to advance in this article. In short, these propositions concern both rationalist (logical) qualities of the cognising subject and rationalist (logical) qualities of the object of their (scientific) experience.
\end{abstract}

Keywords: realistic metaphysics, cognising subject, fundamentals of cognition, convention, usage

\section{Wstęp}

Zapewne nie ma wątpliwości co do tego, że podmioty ludzkie komunikują się z innymi ludzkimi podmiotami. Nie ma także wątpliwości co do tego, że podmioty ludzkie wyrażają swoje intencje komunikacyjne w różnych modalnych wymiarach i za pośrednictwem różnych medialnych instrumentów. Wątpliwości nie budzi także fakt, iż podmioty ludzkie, komunikując się ze sobą, nie wyrażają w pełni, lub w ogóle nie wyrażają swoich intencji komunikacyjnych mimo, iż działają w planie aktów (il-)lokucyjnych. $Z$ całą pewnością możemy powiedzieć również to, że podmioty ludzkie realizują swoje komunikacyjne cele, o tyle, o ile uznają, że działanie innych pomiotów (interlokutorów) spełnia ich kryteria wyrażone w planie aktów perlokucyjnych. Jeżeli uznają, że spełnia, to mówimy, że podmioty te skomunikowały się lub, że się (ze sobą) porozumiały. Ale co takie stwierdzenie właściwie implikuje? Jaka jest podstawa tego skomunikowania: realna czy relatywna? Tytuł niniejszego artykułu nie pozostawia, jak sądzę, wątpliwości co do mojego stanowiska w tej sprawie. Przyjrzyjmy się jakkolwiek temu zagadnieniu z bliska.

\section{Triada $^{1}$}

Problem podstawy komunikacji zamierzam rozstrzygnąć na drodze następującej argumentacji: teza: (1) Istnieje realna podstawa komunikacji; antyteza: (2) Nie istnieje

\footnotetext{
${ }^{1}$ Triady ,teza-antyteza-synteza' nie należy wiązać z paradygmatem metodologicznym Georga W.F. Hegla; nie należy jej tym samym wiązać z twórczością Karola Marksa, który pozostawał pod dużym wpływem filozofii Hegla. Triada stanowi wyłącznie o sposobie argumentacji i organizacji formalnej niniejszego wywodu.
} 
realna podstawa komunikacji oraz synteza: (3) Podstawa komunikacji jest racjonalna, jest w związu z tym logiczna, i to niezależnie od tego, czy istnieje ona realnie, czy też zaistniała jako akcydens.

\section{«Podstawa»}

Zanim przejdę do właściwej argumentacji, konieczna jest na początek refleksja dotycząca tego, jak można w ogóle rozumieć «desygnaty» wyrażenia ,podstawa' - desygnaty, które są kluczowe dla zrozumienia tego, co (nie) jest realnie istniejące, co (nie) bytuje. Istotne jest w tym względzie odróżnienie bytu jako bytu (w jego istocie) od orzekania o bycie (jedynie na podstawie jego przejawów) - chodzi tutaj między innymi o uniknięcie błędu, polegającego na utożsamianiu sposobu poznania rzeczy ze sposobem ich realnego istnienia (zob. A. Maryniarczyk 2005: 77-78).

Otóż w odniesieniu do (lektalnego) komunikowania się, podstawę można by wiązać z jakimś konkretnym (ożywionym lub nieożywionym) bytem oraz z jego właściwościami. Podstawę może stanowić na przykład jakiś komunikujący się podmiot czy też, dajmy na to, mikrofon, którego ten podmiot używa dla komunikowania się na odległość. Co do właściwości konkretnego bytu wypada powiedzieć przede wszystkim to, że winny być one względnie stabilne. Brak stabilności bytu pod względem jego właściwości skutkuje brakiem stabilności podstawy komunikowania się. Wyobraźmy sobie przykładowo sytuację, w której komunikujący się podmiot, nie mając ani względnie stabilnej językowej wiedzy ani względnie stabilnych umiejętności jej przetwarzania, tworzy i artykułuje wyrażenia w niestabilnej funkcji znaczeniowej czy też składniowej. Wyobraźmy sobie inną sytuację, w której komunikujący się podmiot próbuje nawiązać kontakt ze swoim interlokutorem za pośrednictwem mikrofonu, którego (techniczne) właściwości nie umożliwiają względnie stabilnego przetwarzania dźwięku; co więcej, które stanowią o tym, że mikrofon w swej (wewnętrznej) strukturze się po prostu rozpada (zob. relative Stabilität des Selbstbewusstsein und Selbstkonzepts, M. Pauen 2007: 143).

Podstawę komunikowania się można by jakkolwiek wiązać także z jakąś zasadą czy też z (formalną) konwencją ustanowioną w odniesieniu do jakiegoś (kulturowojęzykowego) uzusu² (konwencja jako uzus językowy zob. I. Dąmbska 1975: 38-67). W tym przypadku podstawę komunikowania się można by upatrywać na przykład w jakiejś gramatycznej lub kulturowej regule (postępowania) - regule rozumianej zarówno jako jakiś byt idealny ${ }^{3}$, będący wynikiem formalnej sankcji, jak i jako wynik

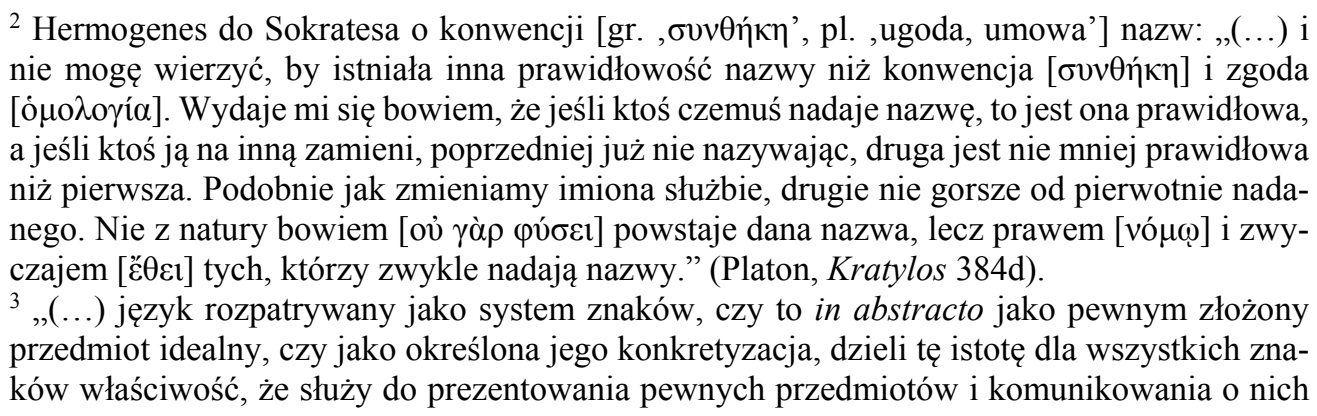


(poznawczej) konceptualizacji podmiotu, tj. branych przez niego pod uwagę (kulturowo-językowych) wyrażeń, a więc jako jego wiedza o znaczeniowych, komunikacyjnych, dyskursywnych etc. funkcjach tych wyrażeń. Dodam na marginesie, że wiedza od bytu idealnego różni się tym, że jest składnikiem konkretnego podmiotu. Nie jest ona bynajmniej składnikiem jakiegoś fenomenu czy też nawet najbardziej konkretnego abstraktu. O ile w pierwszym przypadku mamy do czynienia $\mathrm{z}$ «podmiotem», a więc $\mathrm{z}$ bytem realnie istniejącym - mówiąc językiem filozoficznym, $\mathrm{z}$ bytem istniejącym aktualnie i samym w sobie w pełni określonym (por. B. Paź 2011: 837) o tyle w drugim przypadku wypada nam określić (kulturowo-językową) «konwencję» zarówno jako byt idealny, jak i jako byt realny, ponieważ ukonstytuowany substancjalnie w mózgu konkretnego podmiotu. $\mathrm{O}$ istocie «konwencji» jako bycie realnym pragnę, nie uprzedzając końcowych wniosków, powiedzieć na razie tylko to, że jest on bytem zasadniczo zdarzeniowym, - tj. bytem, którego przyczyna nie leży w nim samym, lecz w podmiotach tenże byt konstytuujących (por. Arystoteles, Metafizyka $1065 b, 1071 b)^{4}$.

Powszechne rozumienie wyrazu ,konwencja' jest cokolwiek inne. «Konwencja» to jakiś rodzaj społecznej umowy, rodzaj jakiejś ustalonej normy. Takie rozumienie odzwierciedla, bądź co bądź, definicja leksykograficzna Słownika Języka Polskiego, której jeden z wariantów ,znaczeniowych' brzmi: «ogólnie przyjęte w jakimś środowisku normy postępowania, myślenia» (por. SJP). Rodzi się w świetle tej definicji pytanie o status desygnatu tego wyrazu. Mówiąc bardziej dosadnie, w jakiej przestrzeni i przez jaki osobowy podmiot miałaby się konstytuować ta «konwencja»? Czyżby miałaby się ona konstytuować „w środowisku”? Jaki sprawczy podmiot miałby się do jej wytworzenia przyczyniać? Na pierwszy rzut oka widać, iż zarówno rozumienie, jaki i formalna definicja niemalże wprost wynikają z łacińskiego źródłosłowu ,conventǐo', pl. ,zgromadzenie, umowa'. [łac. ,convěnı̌o', pl. ,gromadzić się, spotykać się', tj. łac. ,cum', pl. ,z' oraz łac. ,věnǐo', pl. ,przybyć, zjawiać się', por. LD]. Należy domniemywać, że u podstaw konstrukcji znaczenia tego wyrażenia leżało mniemanie, iż w wyniku jakiegoś zgromadzenia konstytuuje się dosłownie $w$ pośrodku tegoż zgromadzenia jakaś «umowa», która miałaby być wspólna wszystkim gromadzącym się podmiotom. Tymczasem rozumiana w ten sposób «umowa» nie

informacji, które to funkcje pełni na zasadzie konwencji. Konwencje te nie są dowolne, lecz pragmatycznie uzasadnione względem na sprawność instrumentalną owego systemu znakowego. Konwencje nadające sens wyrazom (...) mają charakter konwencji, (...) umowy (...) decyzji." (I. Dąmbska 1975: 66).

${ }^{4}$ Powiedzielibyśmy (...), że byt możnościowy jest dzięki przyczynie sprawczej, (...) jego istnienie nie pochodzi z niego samego, lecz z innej rzeczy, która jest «bytem stworzonym». Powiedzielibyśmy też, że ostateczne przyczyny sprowadzają się do bytu koniecznego i że byt konieczny jest jeden. Jest więc jasne, że świat ma pierwszą przyczynę, która nie jest podobna do świata. Z niej wywodzi się byt świata. Jej byt jest konieczny, jest bowiem nie tylko bytem przez się, lecz ponadto jest istnieniem absolutnym i bytem absolutnym. Wszystkie rzeczy czerpią swój byt z niej, tak jak słońce, które samoistnie ma jasność, a dla wszystkich pozostałych rzeczy świecenie jest przypadłością wynikłą ze słońca. (...) Byt konieczny nie ma przedmiotu, istnieje przez siebie. (Awicenna, Księga wiedzy, 1974: 134-135 cyt. za W. Stróżewski 2006: 100). 
może być udziałem podmiotu w sensie substancjalnym, ponieważ w planie ontologicznym jest ona abstraktem. Desygnat wyrażenia ,umowa' nie istnieje realnie, jego (onto-)logiczny status to fenomen - pomijam w tym miejscu warianty ,znaczeniowe' stanowiące o «umowie» jako pisemnym dokumencie, nie są one bowiem istotne dla niniejszego wywodu. Podobnie «konwencja» nie może - jakkolwiek niedorzecznie to brzmi - ,zaistnieć' jako «umowa» w przestrzeni komunikacyjnej, czy też „w środowisku", jak chcą Autorzy Stownika, o ile nie zaistnieje ona wcześniej w umyśle konkretnego podmiotu jako realny wytwór jego, i tylko jego, pracy poznawczej -, kiedy jakąś konwencję kreuje (np. Członek Rady Języka Polskiego), lub pracy absorbcyjnej -, kiedy jakąś konwencję przyswaja (np. uczeń IV Liceum Ogólnokształcącego im. Adama Mickiewicza w Warszawie). I choć «konwencja» zaiste jest wynikiem interakcji podmiotów w ramach ich zbiorowości, to przecież (nieodłącznie) pozostaje składnikiem konkretnego podmiotu, nie zaś zbiorowości jako zbioru, tj. arytmetycznej sumy, tychże podmiotów. Mam tutaj między innymi na myśli tak zwaną ,relację zstępującą', o której będzie mowa poniżej.

Chociaż w przypadku podmiotu i konwencji jako podstawie komunikowania się mamy do czynienia $\mathrm{z}$ dwoma różnymi sposobami bytowania tej «podstawy», a $\mathrm{w}$ związku z tym z dwoma różnymi aspektami orzekania o niej, to jednak oba te sposoby i aspekty łączy fakt, iż «podstawa» - o ile ma spełniać funkcję podstawy skutecznego komunikowania się - to byt istniejący realnie; byt, którego bytowania nie można poddać w wątpliwość, o ile przyjmuje się, że komunikacja (lektalna) jest w ogóle możliwa. Niestety, podobnie jak w przypadku wyrazu ,konwencja', tak też i w przypadku wyrazu ,podstawa', ani «podmiot» ani «realność» bytowania «podstawy» nie znalazły odzwierciedlenia w definicjach konsultowanych przeze mnie słowników języka polskiego. Trzy zasadnicze, a zarazem najczęściej notowane, warianty ,znaczeniowe' wyrazu ,podstawa' to: (1) «rzecz, na której coś stoi, opiera się», (2) «zasada, podwalina czegoś», (3) «podstawa jakiegoś systemu, jakichś poglądów, działań itp. to główne ich założenia lub zasadnicze elementy» (zob. SJP, ISJP, t. 2: 133).

\section{Teza}

Przejdźmy teraz do uzasadnienia tezy w brzmieniu: Istnieje realna podstawa komunikacji. Już sam fakt, że możemy pomyśleć «COŚ»-w tym wypadku możemy pomyśleć ,podstawa' -, świadczy o tym, że istnieje w naszej sferze mentalnej jakiś koncept lub (węższe) pojęcie czegoś, co tak określamy, co, mówiąc ściślej, włączamy w zakres leksemu ,podstawa'. Problem tego, czy to «COŚ» istnieje jako jakiś mentalny potencjał utrwalony w pamięci długotrwałej, czy też jako jakieś limitowane temporalnie zdarzenie, będące wynikiem pracy pamięci operacyjnej, pozostawiam na razie poza nawiasem. Fakt pomyślenia «CZEGOŚ» stanowi w każdym razie przesłankę, aby uznać, że nawet sam akt pomyślenia nie byłoby możliwy, gdyby nie zaistniał, powiem więcej, gdyby nie istniał podmiot tego aktu. Tenże podmiot, aby pomyśleć «COŚ», musi przede wszystkim mieć (jakąś) poznawczą podstawę tegoż pomyślenia; tę podstawę w innym miejscu nazywam ,Erkenntnisbasis' [pl. , podstawa poznawcza'] (zob. G. Pawłowski 2017: 34-48). Ponieważ wiedza (podmiotu) ani nie jest, ani nie po- 
wstaje w izolacji, podmiot musi ponadto wydzielić pewien szerszy lub węższy przedmiotowy zakres/ jakąś (specjalistyczną) ramę, przez którą lub $w$ której taki akt się będzie konstytuował. Przyjąwszy natomiast cele ściśle poznawcze podmiot musi się liczyć także z tym, że rama, jaką wydzielił, nie będzie stanowić dostatecznej podstawy dla wytworzenia nowej wiedzy. Będzie on w związku z tym musiał zrewidować starą lub skonstruować zupełnie nową ramę, aby akt poznawczy w jego mentalnej sferze miał szansę w ogóle zaistnieć.

Przyjrzyjmy się zagadnieniu, które wiąże się z wyrazem ,realny’. Obowiązek lingwisty skłania mnie do zasięgnięcia informacji odnośnie definicji leksykograficznej tego wyrazu: «coś, co jest realne, istnieje w rzeczywistości, a nie tylko w czyichś zamierzeniach, deklaracjach lub wyobraźni» (por. ISJP, t. 2: 421). Realny to także «odznaczający się realizmem lub zdrowym rozsądkiem» (por. SJP). Jak należy rozumieć tę definicję w świetle komunikatywnych funkcji wyrazu ,realny', to znaczy funkcji, które przypisują mu członkowie polskojęzycznej wspólnoty kulturowej. «Realny» to taki, który (przede wszystkim) istnieje, zaś cechy tego istnienia łączone są przez członków tej wspólnoty ze sferą rozumu, a więc ze sferą, w której mamy do czynienia z wnioskowaniem logicznym, z wnioskowaniem wynikowym. Członkowie antycznych wspólnot cywilizacji łacińskiej rozumieli desygnat «realny» nieco inaczej. I tak na przykład średniowieczny przymiotnik ,realis' - od łacińskiego rzeczownika ,rēs' [pl. ,rzecz, przedmiot'], odwoływał do desygnatów pochodnych, takich jak «rzeczowy», «istotny» (por. DHW: 576) oraz do tego, «co istnieje», «co się wydarza» - dwa ostatnie desygnaty zanotowano w średniowiecznych źródłach z wysp brytyjskich (por. $\triangle$ OГEION, Dictionary of Medieval Latin from British Sources). Jakie płyną z tego wnioski wobec poruszanej tutaj kwestii? (a) Coś, co jest, a więc jakiś ontyczny byt ( $\left.\kappa \alpha \theta^{\prime} \alpha u ̛ \tau o\right)$, bądź też (b) coś, co się wydarza, tzn. jakiś fakt, jakaś przy-

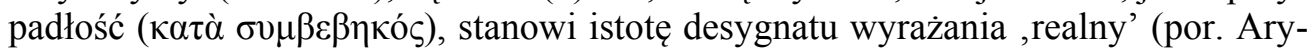
stoteles, Metafizyka 1017a). Na marginesie dodam, że już tylko sam predykat ,jest' wyraża w rodzinie języków indoeuropejskich (jakiś) akt istnienia (por. M.A. Krąpiec 2005: 462). Bynajmniej nie chcę przez to powiedzieć, że li tylko językowe wyrażenie aktu istnienia (jakiegoś) bytu przez istniejący podmiot tenże akt istnienia bytu konstytuuje. Gdybym zarysował taką implikaturę, wkroczyłbym na teren teologii dogmatycznej. Chcę powiedzieć przede wszystkim to, że istnienie, a więc realność, ontycznych bytów jest oczywiste, i implikuje współistnienie materii i formy jako konstytutywnych i niezbędnych składników każdego realnego bytu. Oznacza to, że nie istnieje (na tym świecie) materia bez żadnej formy (por. Tomasz z Akwinu, Sum. Teol. Człowiek II, zag. 89, art. 2); „(...) materia tylko dzięki formie, jej organizacji może być realnym bytem, czyli może rzeczywiście istnieć. Stąd sprzeczne jest istnienie materii bez żadnej formy.” (M.A. Krąpiec 1978, cyt. za A. Maryniarczyk 2005: 45). Składniki realnego bytu (materia i forma) wchodzą ze sobą w realne relacje, są wobec siebie niesprzeczne i stanowią o analogii wewnątrzbytowej tegoż realnego bytu. (por. także M.A. Krąpiec 1978: 238-239, 374-375, A. Maryniarczyk 2005: 13, Arystoteles, Metafizyka 1014a). Zakładam w związku z tym, że realność, a tym samym składnikowa niesprzeczność oraz analogia wewnątrzbytowa konkretnego podmiotu ludzkiego jest sprawą bezdyskusyjną. 
Cóż w tym świetle wypada twierdzić o realności języka, a cóż o realności konwencji? Język, będący dosłownie własnością konkretnego podmiotu, nie jest co prawda bytem ontycznym. Nie jest on bytem, który dałoby się (na chwilę obecną) oddzielić od myślenia i bytowania podmiotu jako takiego. Język jest jakkolwiek bytem realnym, ponieważ jest ukonstytuowany substancjalnie i formalnie w mózgu konkretnego podmiotu. To samo trzeba powiedzieć o konwencji, o ile rozpatrujemy jej istotę, nie zaś powszechne rozumienie. Nie istnieje ona zawieszona, powiedzmy, w jakiejś niedookreślonej przestrzeni komunikacyjnej, lecz jest własnością konkretnego realnego podmiotu, ściślej, jest poznawczym uogólnieniem branych przez niego pod uwagę elementów jakiegoś konceptu lub węższego pojęcia. Podkreślam zarazem, że konwencja nie jest wynikiem uogólnienia bytów realnych jako takich, np. rzeczywistych składników stołu, czy rzeczywistych aktów komunikacyjnych. I tak jakaś reguła gramatyczna, np. reguła (sankcja) dotycząca fleksji jakiegoś wyrazu, nie jest bytem ontycznym, lecz własnością konkretnego realnego podmiotu, będącego na przykład członkiem jakiejś komisji ds. językowej normalizacji i/ lub, bądź też podmiotu realizującego ją w językowych aktach komunikacyjnych. Jest ona, podobnie jak język, realna, ponieważ ukonstytuowana przez realnie istniejący podmiot. Reguła fleksyjna jest zatem wynikiem pracy poznawczej lub absorbcyjnej podmiotu, zmierzającego do wyodrębnienia mentalnych elementów dotyczących fleksji (!) leksemu, jako elementów istotnych, innych zaś jako nieistotnych, celem ukonstytuowania jakiegoś mentalnego faktu, który nazywam zdarzeniem mentalnym (por. Arystoteles, Metafizyka 1064b-1065b, M.A. Krąpiec 1978: 235).

Pod warunkiem uznania pluralizmu jako faktu, a zarazem odrębności bytowania podmiotów i rzeczy, zdarzenie to, leksem, można określić jako zdarzenie realne. Ma się rozumieć, że zarówno leksem, jak i reguła (fleksyjna), będąca zdarzeniem temporalnym w pamięci operacyjnej, nie mogłaby zaistnieć, gdyby nie było odpowiedniego substancjalnego potencjału (wiedzy), oraz gdyby nie było odpowiedniej wiedzy operacyjnej dla jej realizacji (umiejętności). Nie opuszczając paradygmatu metafizycznej relacyjności bytów, w ramach którego byt zdarzeniowy (przygodny) nie jest wcześniejszy od bytu samoistnego (koniecznego) (por. Arystoteles, Metafizyka 1065b), nie pozostaje mi na ten moment nic innego, jak przyznać, że empiryczne uzasadnienie językowej reguły, a tym samym uzasadnienie (jakiejkolwiek innej, np. kulturowej) konwencji, nie jest w świetle powyższego zadaniem prostym. Najnowsze instrumenty obrazowania pracy centralnego systemu nerwowego w zakresie funkcji językowych umożliwiają zasadniczo obserwację tylko aktywnych areałów; umożliwiają zatem diagnozę jedynie aktualnego zdarzenia, nie zaś zasobów, które są jego realną podstawą. Rozpatrując problem konwencji w odniesieniu do zarysowanych wyżej mentalnych wymiarów można pokusić się o jedynie bardzo ogólną diagnozę desygnatów wyrażenia ,konwencja', a mianowicie: «konwencja» to zarówno potencjał, jak i aktualne zdarzenie z tegoż potencjału wynikające (zob. aktualizacja potencji, Arystoteles, Metafizyka 1047b-1048b).

Podsumowując rozważania dotyczące tezy w brzmieniu: istnieje realna podstawa ko- 
munikacji, stwierdzam: realność, wiążąca w sobie aktualność materii i formy w konkretnym i wewnętrznie niesprzecznym bycie, jest faktem (onto-)logicznym. Faktem jest także to, że poznający podmiot nie tylko istnieje, lecz jest także bytem ontycznym. Podmiot istnieje realnie, niezależnie od tego, czy orzekamy o nim, że realnie istnieje. Język tegoż podmiotu jest bytem względnym, istnieje on bowiem o tyle, o ile istnieje jakiś konkretny podmiot. Relacja podmiotu wobec języka jest relacją zstępującą pierwszy byt warunkuje byt drugi (por. A. Maryniarczyk 2005: 87-99). Natomiast konwencja - rozumiana w sposób, w jaki przedstawiono wyżej - jest przede wszystkim bytem zdarzeniowym. Istnienie konwencji wyraża się bowiem poprzez aktywowanie jej do pamięci operacyjnej podmiotu, działającego ze względu na konkretny cel aktów komunikacyjnych oraz działającego wobec faktu, iż konkretne funkcje tych aktów nie mogłyby zaistnieć bez uprzedniego ukonstytuowania się kontekstu wewnętrznego (ramy) i/ lub zewnętrznego (konsytuacji). Dlatego zarówno realność aktów komunikacyjnych jako takich realizowanych w wymiarze jakiejś wspólnoty kulturowej - mamy tutaj do czynienia z konkretnym temporalnie osadzonym zdarzeniem komunikacyjnym, jak i realność konwencji jako zdarzenia mentalnego, i to przede wszystkim ze względu na realność genetycznego i językowego potencjału, z jakiego ona wynika, jest moim zdaniem oczywista.

\section{Antyteza}

W celu uzasadnienia antytezy w brzmieniu: nie istnieje realna podstawa komunikacji, przeprowadźmy następujący eksperyment, dzieląc go na dwa etapy. Etap pierwszy: RELATYWISTYCZNA WIZJA PODMIOTU. Byt ontyczny, jakim w przypadku rozpatrywanej tutaj komunikacji, jest (istotowo) człowiek, traktujemy jako byt akcydentalny. Człowiek jawi się w tej wizji nie tylko - co oczywiste - jako byt przemijający, limitowany temporalnie, lecz jawi się on nam przede wszystkim jako jakiś zdarzeniowy fenomen. Jego (onto-)logiczny status oraz właściwości mają w związku z tym charakter względny. Każdy fenomen jest wprawdzie (onto-)logicznym faktem o jakichś konkretnych cechach, jakkolwiek faktem nie ukonstytuowanym podmiotowo (osobowo) - faktem, który nie wynika sam z siebie, lecz z czegoś lub kogoś, będącego poza nim. Człowiek, będący fenomenem, jest w tej wizji bytem względnym, bytem, który po prostu nie jest podmiotem - podmiotem rozumianym przede wszystkim jako byt sprawczy. Człowieka nie konstytuuje «istota», lecz jedynie «istnienie». Nie posiada on składników bytowych (substancjalnych), lecz składniki przypadłościowe. Nie jest on uformowany z materii, lecz istnieje wyłącznie w postaci formy (zob. istota vs. istnienie M.A. Krąpiec 1978: 402, por. także M.A. Krąpiec 2005: 449). Etap drugi: PODMIOTOWA WIZJA KONWENCJI. Przyjmijmy, że byt akcydentalny, za jaki się w językoznawstwie zazwyczaj uważa «konwencję», nie jest uprzyczynowany. Nie jest, nie bytuje on zarówno w planie relacji skutkowo-przyczynowej, jak i w planie relacji skutkowo-celowej - nie jest on partycypantem (zob. M.A. Krąpiec 1978: 160-161, także relacyjność bytowa i teoria partycypacji Z.J. Zdybicka 2005: 91). Byt ten istnieje sam przez się, nie potrzebuje w związku z tym podmiotu, który byłby jego przyczyną -, który byłby jego przyczyną sprawczą. Byt ten jest sam dla siebie podmiotem, byt ten, «konwencja» sama jest podmiotem. Wizja ta nie jest bynajmniej tak niedorzeczna, 
jakby się nam mogło wydawać na pierwszy rzut oka. Przypomnę tylko, że poważne próby ontologizacji, co więcej, absolutyzacji języka miały już w historii miejsce. Zbliżoną wizję kreuje przykładowo Martin Heidegger w monografii pt. Unterwegs zur Sprache. Według Heideggera ,język mówi”, ,jego (języka) mówienie mówi dla nas w tym, co powiedziane" (cyt. za B. Wald 2005: 424, krytycznie o hermeneutyce filozoficznej oraz konstytutywnym antropocentryzmie hermeneutyki humanistycznej $W$. Diltheya 424-432, 437, także Martin Heideggers Vortrag vom 7. Oktober 1950 zum Gedächtnis von Max Kommerell por. M. Heidegger 1971: 11-33) ${ }^{5}$.

Jaki obraz wyłania się z tego eksperymentu? W tej zaiste skrajnie relatywistycznej wizji «człowieka» oraz ze wszech miar hermeneutycznej (postmetafizycznej) wizji «konwencji», podstawy w ogóle oraz podstawy komunikacji w szczególe nie stanowi człowiek, lecz konwencja (!). Człowiek nie jest, lecz (tylko) jawi się (nam) - tzn. właściwie komu? - jako fenomen. Natomiast konwencja, będąca podobnie jak język podmiotem, aktywuje funkcje, które przystoją (istotowo) wyłącznie podmiotom sprawczym - konwencja jest zatem bytem sprawczym.

$* * *$

Jak się w tym świetle przedstawia problem podstawy realnej w kontekście naszej antytezy: Nie istnieje realna podstawa komunikacji. W wizji nakreślonej w powyższym eksperymencie mamy do czynienia z radykalną zmianą, wskutek której człowiek traci swoją sprawczą właściwość na rzecz konwencji. Konwencja, będąc podmiotem staje w centrum aktów komunikacyjnych. Konwencja jest zarówno podstawą, jak i źródłem tych aktów. Skoro jest ona podmiotem sprawczym, to należy wnioskować, że jest bytem ontycznym. Przy jednoznacznej absencji człowieka jako sprawczego podmiotu konwencja, będąc sprawczą musi po prostu realnie istnieć. Ta konstatacja może się wydawać zaskakująca, bowiem nie różni się ona od tej wyrażonej w kontekście tezy niniejszego artykułu; przypomnę: «konwencja» jest istotowo bytem zdarzeniowym i realnie istniejącym w umyśle konkretnego podmiotu. Co ciekawe, ta sytuacja nie dotyczy samego podmiotu. Podmiot kompletnie zmienia swój status oraz właściwości.

\footnotetext{
5 „Sprache ist Sprache, wie soll dies uns weiterbringen? Wir wollen jedoch nicht weiterkommen. Wir möchten nur erst einmal eigens dorthin gelangen, wo wir uns schon aufhalten. Darum bedenken wir: Wie steht es mit der Sprache selbst? Darum fragen wir: Wie west die Sprache als Sprache? Wir antworten: Die Sprache spricht. Ist dies im Ernst eine Antwort? Vermutlich schon denn nämlich, wenn ans Licht kommt, was sprechen heißt. Der Sprache nachdenken verlangt somit, daß wir auf das Sprechen der Sprache eingehen, um bei der Sprache, d. h. in ihrem Sprechen, nicht in unserem, den Aufenthalt zu nehmen. Nur so gelangen wir in den Bereich, innerhalb dessen es glückt oder auch mißglückt, daß aus ihm die Sprache uns ihr Wesen zuspricht. Der Sprache überlassen wir das Sprachen.” (M. Heidegger 1971: 12). „Die Sprache spricht. Der Mensch spricht, insofern er der Sprache entspricht. Das Entsprechen ist Hören. Es hört, insofern es dem Geheiß der Stille gehört.” (op. cit. 32-33). „Das Vermögen zu sprechen ist auch nicht nur eine Fähigkeit des Menschen, gleichgeordnet seinen übrigen. Das Vermögen zu sprechen zeichnet den Menschen zum Menschen aus. Die Zeichnung erhält den Aufriß seines Wissens. Der Mensch wäre nicht Mensch, wenn ihm versagt bliebe (...), in mannigfaltigen Abwandlungen und zumeist unausgesprochen in einem es ist zu sprechen. Insofern die Sprache solches gewährt, beruht das Menschenwesen in der Sprache.” (op. cit. 241).
} 
Nawet jeżeli bardzo chcielibyśmy uznać tę wizję za uzasadnioną, to wciąż nie jest jasne, jaką funkcję podmiot miałby w tej wizji właściwie spełniać, szczególnie zaś w obliczu faktu, iż to konwencja przejmuje funkcję intencjonalności aktów komunikacyjnych. Czyż podmiot miałby spełniać funkcję li tylko idealnego desygnatu? Wydaje się to cokolwiek kuriozalne. Tak, jak niejasne są funkcje «podmiotu», tak samo niejasne są właściwości «konwencji», które wypadałoby zaakceptować w konsekwencji powyższego eksperymentu. Mam tu na myśli szczególnie jedną właściwość, a mianowicie «sprawczość». Wątpliwość co do tej właściwości w kontekście naszego eksperymentu polega na tym, że nie sposób jej racjonalnie uzasadnić, nie negując jednocześnie pluralizmu jako właściwości generalnej - właściwości, będącej udziałem bytu, jaki znamy. Czyż, negując pluralizm, nie musielibyśmy przyjąć monizmu jako zasady istnienia? Jakże miałaby wówczas wyglądać komunikacja? Czy byłaby ona w ogóle potrzebna?

Przyjrzyjmy się teraz problemom, jakie wynikają z rozumienia ,konwencji’ jako społecznej umowy; powtórzmy cytowaną wyżej definicję: «Ogólnie przyjęte w jakimś środowisku normy postępowania, myślenia». Uznając tę definicję za wiążącą, musimy przyznać, że «konwencja», będąc bytem idealnym zawieszonym w komunikacyjnej próżni nie jest realnym bytem, a komunikacja, jaką znamy, nie wydaje się być w ogóle możliwa. Trudno się tutaj po prostu doszukać jej realnej podstawy, ponieważ zarówno człowiek, będący fenomenem, jaki i konwencja, będąca podmiotem nie są realnie umocowani - ich status (onto-)logiczny jest co najmniej niejasny. Mówiąc bardziej jednoznacznie, takie obiekty, jak «człowiek» i «konwencja» są nierealne. Jeżeli przyjmiemy tę wizję jako obowiązującą w komunikacji (lektalnej), wówczas winniśmy przyznać, że komunikacja - skoro jest możliwa- musi przecież mieć jakąś podstawę. W innym przypadku nie mogłaby w ogóle zaistnieć. Dlatego nie pozostaje nam nic innego jak przyjąć, że ta podstawa po prostu nie istnieje realnie, lecz przypadłościowo; musi się ona jawić jako relatywna, jako względna, a wizja ludzkiej komunikacji zaiste jako skrajnie relatywistyczna. Względna podstawa komunikacji jest skądinąd tworem wewnętrznie sprzecznym. Bowiem podstawa, będąca li tylko przypadłością, ,musi’ implikować jakiś realny obiekt, którego cechy współkonstytuuje. Przypadłość nie jest bytem ontycznym, nie jest w związku z tym bytem o względnie stabilnej strukturze bytowej (jak wyżej M. Pauen 2007: 143). Nie można się zatem skomunikować kimś kto ma lub - jakkolwiek niedorzecznie to brzmi - kto obrał akurat inną podstawę komunikacji, to znaczy, jakiś istotowo inny zbiór przypadłości.

Idąc dalej winniśmy przyznać, że mamy tutaj do czynienia nie tylko ze względną - a w związku z tym podlegającą ciągłej zmianie - podstawą komunikacji, lecz po prostu z permanentną aporią. Aporia ta polega przede wszystkim na tym, że o skutecznej komunikacji decyduje dosłownie przypadek. Jak bowiem wyjaśnić fakt zaistnienia dwóch niezależnych wobec siebie podstaw komunikacji w tym samym czasie. Co więcej, jak wyjaśnić fakt, iż w bycie zdarzeniowym, jakim jawi się w tej relatywistycznej wizji człowiek, i w innym bycie zdarzeniowym, jakim jawi się inny człowiek, zaistniała analogiczna podstawa komunikacji. Jaką podstawę miałaby mieć tutaj sama analogia? Czyż o podstawie komunikacji i analogii miałaby dosłownie decydować jakaś językowa konwencja? Czyż o podstawie komunikacji i analogii miałby decydować przypadłość? 


\section{Synteza}

Przejdźmy teraz do uzasadnienia syntezy w brzmieniu: Podstawa komunikacji jest racjonalna, jest logiczna, niezależnie od tego, czy istnieje ona realnie, czy też zaistniata jako akcydens. Jedno z pierwszych pytań, jakie nasunęło mi się podczas refleksji nad zagadnieniem dotyczącym podstawy komunikacji, brzmiało: dlaczego komunikacja jest możliwa? Nie chodzi tutaj bynajmniej o zdanie orzecznikowe w rodzaju: ,Skoro ludzie się porozumiewają, stwierdzam, że komunikacja jest możliwa'. Chodzi tutaj ze wszech miar o pytanie przyczynowo-skutkowe: Dlaczego tak się dzieje, że ludzie się porozumiewają? Jest to jednocześnie pytanie o (realną) podstawę samego

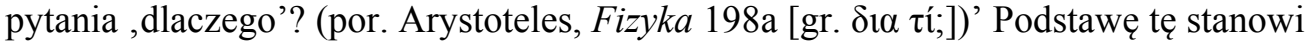
nie tylko uporządkowany, lecz przede wszystkim uprzyczynowiony paradygmat istnienia wszystkich bytów, procesów i zdarzeń. Paradygmat, w którym relacyjność bytowa a zarazem wynikowość, będąca istotą myślenia, tj. tworzenia relacji pomiędzy obiektami (mentalnymi), mają swoje realne źródło. Nie będę, rzecz jasna, omawiał tej kwestii w tej chwili, dodam tylko w duchu tomizmu egzystencjalnego reprezentowanego przez lubelską szkołę metafizyki realistycznej, że „,[s]pełnieniem powinności bycia istotą rozumną jest odpowiedź na pytanie: dlaczego jest, skoro nie musi [być]?" (więcej na ten temat por. A. Maryniarczyk 2005: 68, 102).

Wróćmy do kluczowej kwestii: Dlaczego tak się dzieje, że ludzie się porozumiewaja? Syntetyczna odpowiedź na to pytanie brzmi: Dzieje się tak dlatego, że podstawa komunikacji jest racjonalna, że jest logiczna. W tym miejscu należałoby jednocześnie zapytać o fakty, na których oparte jest to stwierdzenie. Uzasadnienie tej kwestii oprę o teorię partycypacji, która została ukonstytuowana przez przedstawicieli wspomnianej wyżej szkoły. Teoria partycypacji sięga idealistycznej wizji Platona, a była przez niego wyrażana za pomocą takich wyrazów jak , $\mu \varepsilon \dot{\theta} \theta \varepsilon \xi 1 \varsigma^{\prime}$ [pl. , uczestnic-

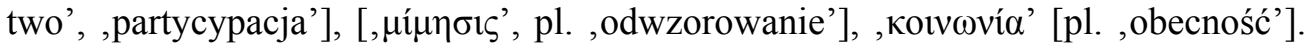
Była to teoria, dzięki której diagnozowano relacje, jakie zachodzą pomiędzy poznawalnymi zmysłowo (zmiennymi) obiektami (rzeczami) a ideami, tj. między tym, co poznawalne intelektualnie (co jest intelligibilne), a samymi ideami. Teoria partycypacji szkoły lubelskiej osadzona jest jednak przede wszystkim w koncepcji metafizyki Tomasza z Akwinu. Teoria ta, zwana także metafizyką partycypacji, stanowi syntezę całego systemu metafizyki analogii, pozwala bowiem wyjaśnić najważniejsze zagadnienia metafizyczne. Ze względu na podejmowany w tym miejscu problem wymienić należy następujące aspekty tej teorii: (1) wewnętrzna struktura bytu, (2) relacje ontologiczne pomiędzy jednym przygodnym bytem a innym przygodnym bytem oraz (3) relacje pomiędzy bytami przygodnymi a - mówiąc za Arystotelesem - „Pierwszym nieporuszonym Poruszycielem" tychże przygodnych bytów. (por. Arystoteles, Fizyka, 198a-b, Metafizyka, 1071a-1073a, Z.J. Zdybicka 2005: 87).

Ontyczną podstawę partycypacji stanowi analogiczna struktura bytu. I tak w punkcie pierwszym chodzi o analogię wewnątrzbytową. Ten zakres analogii dotyczy bytu indywidualnego, tzn. bytu jako bytu oraz właściwości tegoż bytu. Byt jest wewnętrznie niesprzeczny - nie rozpada się, a relacje pomiędzy konstytuentami tegoż bytu są realne, wiążą bowiem byt w jedną inherentną całość. Byt jako spójną całość 
konstytuują wprawdzie jego poszczególne składniki, lecz (arytmetyczna) suma składników nie stanowi o istocie bytu. ${ }^{6}$ Realnie istniejący byt jest sam w sobie analogiczny, a więc racjonalny (uporządkowany). Analogiczna struktura jednostkowego bytu związanego relacjami konstytuujących go składników stanowi podstawę dla analogii międzybytowej. I tak w punkcie drugim, byt, który jest sam w sobie analogiczny, jest jednocześnie analogiczny w stosunku do innych realnie istniejących bytów. Tworzy się w związku z tym analogiczna ,jedność' bytów przygodnych, będących atoli bytami istotowo pluralistycznymi. Co prawda łatwo jest zaakceptować analogię wewnątrz- i międzybytową ze względu na racjonalną strukturę bytu, trudniej jednak mierzymy się z analogią odnoszącą się do „Pierwszego nieporuszonego Poruszyciela” tegoż bytu wyrażoną w punkcie trzecim. Problem dotyczy przede wszystkim podstawy tej analogii, to znaczy racio tejże podstawy. Metafizycy lubelscy utożsamiają ją po pierwsze z faktem, iż byty pochodzące od wspólnego pnia (filogeneza) mają ,taką samą' strukturę bazową (tzn. podstawę poznawczą), a więc są do siebie podobne. Zaistnienie tej struktury implikuje po drugie jakieś realne źródło, w którym te byty partycypują ze względu na swoje konstytuenty, tj. materię i formę (zob. realna transcendencja u Parmenidesa z Elei 540 przed Chr. - 470 po Chr., por. J. Jusiak 1994: 31). Po trzecie, partycypację bytów należy rozumieć bynajmniej nie tylko meronimicznie (część-całość), lecz właśnie ze względu na wspomnianą wyżej realną relacyjność skutkowo-przyczynową i skutkowo-celową. Tak rozumiana relacyjność to realna partycypacja tego, co ,jest częściowo' w tym, co ,jest w pełni'; partycypacja tego, co pochodne w tym, co jest pierwsze. W tym świetle bycie partycypantem oznacza bytować w sposób uprzyczynowany (por. Z.J. Zdybicka, 2005: 91-94, A. Maryniarczyk 2005: 54-55, M.A. Krąpiec 2005: 449, Arystoteles, Metafizyka 1013b, Awicenna, Księga wiedzy, 1974: 134-135 cyt. za W. Stróżewski 2006: 100). Analogiczność bytów w stosunku do sposobu partycypacji tychże bytów i konstytuujących je składników można przedstawić w skrócie następująco: (a) analogiczność każdego bytu - jest to relacja treści (istoty) do aktu istnienia, chodzi tutaj o relację ,możność akt', (b) istnienie realizuje się w konkretnym bycie i jest czynnikiem, który uzasadnia bytowość i realność rzeczy, (c) analogiczna struktura rzeczywistości stanowi ontyczną a zarazem poznawczą podstawę partycypacji. Oznacza to, że byty indywidualne (przygodne), będące same w sobie i względem siebie w relacji analogii (partycypacji) implikują taki byt, który jest pełnią każdego istnienia (por. Z.J. Zdybicka 2005: 89).

Relacyjność bytowa, a związku z tym, skutkowa relacja partycypacji, z konieczności musi dotyczyć także tego, co w filozofii nazywa się ,poznaniem', zaś w lingwistyce ,pracą poznawcząa' (por. Erkenntnisarbeit, Erkenntnishandlung w F. Grucza

\footnotetext{
${ }^{6} \mathrm{~W}$ porządku natury to całość jest racją części (...). Pomiędzy ,częściami’, jako składnikami bytu, i całością istnieje konieczny (...) związek relacyjny. Relacje realne, wiążące części w jedną całość, przebiegają na linii: części - całość, oraz na linii: części - części. Tych ,częściczynników' tworzących jeden byt (np. konkretnego człowieka) jest ponadwyobrażalna ilość (...) a wszystkie te części są związane realnymi relacjami między sobą, tworząc całość. (M.A. Krąpiec 2005: 448-449).
} 
2012: 294-304). Ze względu na znane z przeszłości błędy postmodernizmu (absolutyzacja poznającego podmiotu czy też, wspomniana wyżej, ontologizacja języka) jest w tym miejscu bardzo ważne, aby jasno odróżniać relację skutkowo-przyczynową $\mathrm{i}$ skutkowo-celową, ,zawieszoną' w porządku realnym, od relacji wynikowej/ logicznej, będącej podstawą porządku (procesu) poznawczego - chodzi w skrócie o odróżnienie bytu jako bytu (bytu jako takiego) od jego epistemologicznego ujęcia. Praca poznawcza, będąc wynikową/ logiczną, stanowi realną odpowiedź poznającego podmiotu na analogiczny modus istnienia (bytów) - byt jest bowiem intelligibilny - byt jest racjonalny/ logiczny, byt ,daje się’ poznać. Gdyby było inaczej, to nie bylibyśmy jako poznające podmioty w stanie orzec czegokolwiek o otaczającym nas świecie. Co więcej, dosłownie wszystkie wytwory poszczególnych kultur, i to zarówno w ujęciu indywidualnym (idiokultura), jak i w ujęciu zbiorowym (polikultura), musiałyby być uznane za nieracjonalne/ nielogicznie, lub musiałyby być w każdym razie nazwane inaczej aniżeli racjonalne, niż logiczne. Racjonalna/ logiczna struktura bytu stanowi nie tylko podstawę analogii i partycypacji, lecz warunkuje także to, co nazywam metafizyką myślenia, czytaj: istotą myślenia (por. G. Pawłowski 2018, także wyniki dyskusji w ramach Interdyscyplinarnego Forum Semantycznego: http://fs.uw.edu.pl/dyskusje/). Myślimy i wnioskujemy analogicznie, ponieważ byty, o których myślimy i, o których wnioskujemy jawią się nam jako byty analogiczne. Nie może w związku z tym zaistnieć analogia (racjonalność) we wnioskowaniu, jeżeli tej analogii (racjonalności) nie będzie wcześniej w konstrukcji samych realnych jednostkowych, tj. konkretnych, bytów. (por. A. Maryniarczyk 2005: 53, M.A. Krąpiec 2005: 448-454).

$* * *$

Jakie wnioski lingwistyczne można wysnuć z przeprowadzonej tutaj diagnozy odnośnie realnej podstawy komunikacji? Lingwistyka, będąc nauką, konstytuuje się dzięki i za przyczyna realnej podstawy, jaką jest (poznający) osobowy podmiot. Stąd lingwistyczne koncepcje określane jako relatywistyczne, istotowo, podkreślam istotowo, nie są relatywistyczne, lecz realistyczne, i to zarówno ze względu na realną, ponieważ ontyczną, podstawę podmiotu nauki, jak również ze względu na racjonalną (realną) podstawę wnioskowania, jaką stanowi analogiczna struktura bytu (analogia). Dodam na marginesie, że o realnym bytowaniu języka w świadomości indywiduum oraz o realnych znaczeniach ,wyrazów' pisał już na początku XX w. poprzedniego stulecia polski językoznawca Stanisław Szober (por. S. Szober 1913: 4, 1924: 8, 20). W podobnym duchu wyrażał się także Franciszek Grucza - mam tutaj na myśli nie tylko, [realnie istniejące] obiekty obiektywnej rzeczywistości uniwersum, ale także realnie istniejące (patrz: rzeczywiste) ,idio- i polilekty” (por. F. Grucza 1983: 24, 1997: 80).

I tak przykładowo lingwistyka szkoły warszawskiej w osobach Baudouina de Courtenay, Stanisława Szobera, Franciszka i Sambora Gruczy oraz piszącego te słowa, nie podnosi do rangi podmiotu samego języka, czy też konwencji, jak czynili to wspomniani na początku mentaliści, lecz utożsamia konkretny istniejący podmiot $\mathrm{z}$ realnym osobowym podmiotem, jako tym, który, będąc podmiotem ontycznym, jest zdolny realizować akty ściśle poznawcze (epistemiczne), akty porządkujące (kognitywne) i/ lub akty komunikacyjne (eksponenty aktów mentalnych). Lingwistyka antropocentryczna - zwana w przeszłości relatywistyczną koncepcją języków ludzkich 
- już chociażby z względu na swoją nazwę, odsłania się nam przede wszystkim jako (lingwistyka) realistyczna. O ile pluralizm tej koncepcji można by pod pewnymi warunkami uznać za relatywistyczny - słusznie bowiem konstytuuje się on przez ontologiczną jedność podmiotu, a zarazem jego odrębność wobec innych podmiotów, o tyle już sam fakt, iż językowa komunikacja może w ogóle zaistnieć - i to właśnie pomimo tej pluralistycznej odrębności - świadczy o tym, że nie może się ona (komunikacja) odbywać w próżni niebytu.

\section{Bibliografia}

API $\Sigma T O T E \Lambda O Y \Sigma, T \Omega N$ META TA $\Phi Y \Sigma I K A$. Uniwersytet Narodowy im. Kapodistriasa w Atenach (URL http://users.uoa.gr/ nektar/history/tributes/ancient_authors/Aristoteles/metaphysica.htm). [Pobrano 17.11.2018].

Arystoteles, Metafizyka. Warszawa, 2009.

Dąmbska, I. (1975), O konwencjach i konwencjonalizmie. Wrocław et. al.

DHW, Duden. Das Herkunftswörterbuch. Etymologie der deutschen Sprache. 2., völlig neu bearb. Aufl. Bd. 7. Mannheim/ Wien/ Zürich, 1989.

Grucza, F. (2012), Zum Gegenstand und Aufgaben der anthropozentrischen Linguistik, Kulturologie und Kommunikologie sowie zur gegenseitigen Vernetzung dieser Erkenntnisbereiche. [w:] „Kwartalnik Neofilologiczny”, LIX (3), 287-344.

Grucza, F. (1997), Problemy historii i genezy języków ludzkich, (w:) A. Dębski (red.), Plus Ratio Quam Vis. Festschrift für Aleksander Szulc zum 70. Geburtstag. Kraków, 77-99.

Grucza, F. (1983), Zagadnienia metalingwistyki. Lingwistyka-jej przedmiot, lingwistyka stosowana. Warszawa. Także Franciszek Grucza. Dzieta zebrane. t. 8. Wydanie jubileuszowe z okazji 80. rocznicy urodzin. (red.) S. Grucza, M. OlpińskaSzkiełko, M. Płużyczka, I. Banasiak, M. Łączek. Warszawa, 2017. (URL http://portal.uw.edu.pl/documents/11738337/14640936/FG_Tom_8.pdf). [Pobrano 17.11.2018].

Heidegger, M. (1971), Unterwegs zur Sprache. 4. Aufl. Tübingen.

ISJP, Inny Słownik Języka Polskiego pod redakcją Mirosława Bańko. t. 1-2. Warszawa, 2000.

Jusiak, J. (1998), Metafizyka a poznanie bezpośrednie. Tradycyjny $i$ wspótczesny ksztalt zagadnienia. Lublin.

Jusiak, J. (1994), Myślenie metafizyczne i niemetafizyczne, (w:) „Przegląd Filozoficzny - Nowa Seria", 3(2), 27-44.

Krąpiec, M.A. (2005), Analogia w filozofii, (w:) A. Maryniarczyk/ K. Stępień/ P. Skrzydlewski (red.), Analogia w filozofii (Zadania współczesnej metafizyki 7). Lublin, 447-471.

Krąpiec, M.A. (1978), Metafizyka. Zarys teorii bytu, wyd. 2. Lublin.

LD, A Latin Dictionary von Charlton T. Lewis und Charles Short (URL www.perseus.tufts.edu/). [Pobrano 6.11.2018].

$\Lambda$ ОГЕION, Greek and Latin Dictionary (URL http://logeion.uchicago.edu/index.html). [Pobrano 23.03.2018]. 
Maryniarczyk, A. (2005), O przyczynach, partycypacji i analogii (=Zeszyty z metafizyki 6). Lublin.

Pawłowski, G. (2018), Metafizyka myślenia - syntetycznie o kwestii ,myślenie’ czy ,myślenie specjalistyczne'? (w:) „Applied Linguistics Papers“, 25/1, 51-59.

Pawłowski, G. (2017), Fachlexeme in Konstruktion. Linguistischer Beitrag zur Erkenntnisarbeit. Frankfurt am Main i in.

Paź, B. (2011), Ontologia versus metafizyka? Geneza, rozwój i różne postaci nowożytnej teorii bytu, (w:) ,Filo-Sofija“, 15/4, 817-847.

Pauen, M. (2007), Was ist der Mensch? Die Entdeckung der Natur des Geistes. München.

SJP, Słownik Języka Polskiego PWN (URL www.sjp.pwn.pl). [Pobrano 21.03.2018].

Stróżewski, W. (2006), Ontologia. Kraków.

Szober, S. (1924), Zarys językoznawstwa ogólnego. Warszawa: SN/ Lublin (URL www.polona.pl). [Pobrano 21.03.2018].

Szober, S. (1913), O poprawności języka. Warszawa (URL www.polona.pl). [Pobrano 21.03.2018].

Tomasz z Akwinu, Suma teologiczna. Człowiek, cz. 1. tłum. Pius Bełch. Londyn: Veritas (URL http://www.katedra.uksw.edu.pl/suma/suma_przelad.htm). [Pobrano 23.11.2018].

Wald, B. (2005), Czy potrzebujemy dzisiaj filozofii metafizycznie uzasadnionej? Dlaczego metafizyki nie da się zastąpić hermeneutyką filozoficzną? (w:) A. Maryniarczyk/ K. Stępień/ P. Skrzydlewski (red.), Analogia w filozofii (Zadania współczesnej metafizyki 7). Lublin, 423-446.

Zdybicka, Z.J. (2005), Analogia i partycypacja w wyjaśnianiu rzeczywistości, (w:) A. Maryniarczyk/ K. Stępień/ P. Skrzydlewski (red.), „Analogia w filozofii” (Zadania współczesnej metafizyki 7). Lublin, 87-104. 